\title{
Fell walking injuries in Cumbria: a review
}

\author{
A. Goel, FRCS and A. K. L. Addison, FRCS \\ West Cumberland Hospital, Whitehaven, Cumbria, UK
}

\begin{abstract}
An analysis of injuries sustained during fell walking in Cumbria and seen at the West Cumberland Hospital over a 3-year period is presented. There were 90 patients, including 19 multiple injuries and four deaths. This report focuses attention on the seriousness and magnitude of injuries associated with a pastime often thought to be harmless and risk-free.
\end{abstract}

Keywords: Fell walking injuries

Fell walking in Cumbria is a popular pursuit. This paper describes the injuries sustained by fell walkers presenting to the West Cumberland Hospital, which is one of the three hospitals in the area dealing with such injuries.

\section{Methods}

For all patients seen at casualty (including those brought by private transport, helicopter or ambulance (Mountain Rescue Team) with injuries as a direct consequence of fell walking a form was filled in detailing the nature of injuries, the time and place of accident, and the treatment received. Assessment was also made of the experience of the walker and the suitability of the clothing he or she was wearing.

The injuries were divided into two groups significant and minor. Significant injuries included all head, chest and abdominal injuries needing admission, all fractures and dislocations and hypothermia needing treatment. Minor injuries included abrasions, lacerations, sprains and other soft-tissue injuries.

\section{Results}

The distribution of casualties for the 3-year period, October 1986 to September 1989 is shown in Table 1. A total of 90 patients were seen of whom 54 needed admission; five were sufficiently badly injured to be admitted to the intensive care unit (ICU); and four patients were declared dead on arrival.

There were 66 patients with significant injuries, 19 with multiple injuries (Table 2).

The majority of patients were brought to hospital by ambulance or helicopter. The usual time interval between the accident and arrival at the hospital was $3 \mathrm{~h}$ (Table 3). All the injuries occurred during the daytime and at different places.

Address for correspondence: Mr A. Goel, West Cumberland Hospital, Whitehaven, Cumbria CA28 8JG, UK

(C) 1992 Butterworth-Heinemann Ltd 0306-3674/92/030143-02
No link was found between the experience of the walker, the suitability of their clothing and the nature of injuries sustained.

Orthopaedic injuries usually involved the lower limbs, of which ankle injuries were the most common (Table 4).

\section{Discussion}

Fell walking is becoming increasingly popular, and while we do not know the exact number of participants injured it is probably fairly small.

Still, the injuries recorded over the 3-year period are significant and sometimes fatal.

There are two measures that we feel can reduce the injuries sustained during this sport. The first is proper training in basic mountaineering skills, such as elementary direction finding in bad weather and the importance of using proper footwear, clothing and equipment ${ }^{1,2}$.

Appropriate footwear for wet and snow-covered surfaces would prevent walkers slipping, and would reduce injuries sustained by this mechanism, which gives rise to the largest percentage of injuries (Table 5).

Wearing crash helmets would prevent a significant number of head injuries, especially those due to rock falls. This could perhaps be best done by educational and warning programmes like the ones used in other countries - the Scottish Mountain Safety Group has a similar programme ${ }^{3}$.

Second, in certain areas aids such as fixed belay anchors in steep rock falls and markers indicating routes for walkers in treacherous places could make the place less dangerous. In places where difficult terrain could make evacuation of patients slow, cableways may be of great value.

All this equipment would require regular inspection and servicing, or may itself be a source of danger.

\section{Acknowledgements}

The authors are grateful to Mr I. Pattinson of the Mountain Rescue Team and the nursing staff of the casualty department of the West Cumberland Hospital for their cooperation.

\section{References}

1 Mountain Accidents (1980-1989). Reports issued by the Lake District Search Panel.

2 MacInnes H, London C. International Mountain Rescue Handbook. 2nd ed. Philadelphia, USA: Trans-Atlantic, 1984.

3 MacGregor A. Scottish Mountain Accidents. Sports Med Soft Tissue Trauma 1989; II: 6-8. 
Fell walking injuries in Cumbria: A. Goel and A. K. L. Addison

Table 1. Patients with fell walking injuries (yearly basis)

\begin{tabular}{|c|c|c|c|c|c|c|c|c|c|c|c|c|}
\hline \multirow[t]{2}{*}{ Period } & \multicolumn{3}{|c|}{ No. of patients } & \multicolumn{5}{|c|}{ Age of patients (years) } & \multirow[t]{2}{*}{ Discharged } & \multicolumn{2}{|c|}{ Admitted } & \multirow[t]{2}{*}{ Deaths } \\
\hline & Total & Male & Female & $\leqslant 10$ & $11-18$ & $19-40$ & $41-60$ & $61-80$ & & Total & $I C U$ & \\
\hline $\begin{array}{l}\text { October 1986-September } 1987 \\
\text { October 1987-September } 1988 \\
\text { October 1988-September } 1989 \\
\text { Total }\end{array}$ & $\begin{array}{l}28 \\
32 \\
30 \\
90\end{array}$ & $\begin{array}{l}16 \\
19 \\
21 \\
56\end{array}$ & $\begin{array}{r}12 \\
13 \\
9 \\
34\end{array}$ & $\begin{array}{l}1 \\
1 \\
-\end{array}$ & $\begin{array}{l}6 \\
4 \\
4\end{array}$ & $\begin{array}{l}10 \\
17 \\
12\end{array}$ & $\begin{array}{l}8 \\
6 \\
9\end{array}$ & $\begin{array}{l}2 \\
2 \\
4\end{array}$ & $\begin{array}{l}11(39.3) \\
9(28.1) \\
12(40) \\
32(25.5)\end{array}$ & $\begin{array}{l}16(57.1) \\
21(65.6) \\
17(56.6) \\
54(60)\end{array}$ & $\begin{array}{l}1(3.1) \\
4(13.3) \\
5(5.6)\end{array}$ & $\begin{array}{l}1(3.5) \\
2(6.3) \\
1(3.8) \\
4(4.6)\end{array}$ \\
\hline
\end{tabular}

Values in parentheses are percentages

Table 2. Patients seen over 3-year period with fell walking injuries

\begin{tabular}{lc}
\hline Degree of injury & Number \\
\hline Significant injuries & $66(73.3)$ \\
Multiple injuries & $19(21.1)$ \\
Minor injuries & $20(22.2)$ \\
Deaths & $4(4.4)$ \\
Total & 90 \\
\hline
\end{tabular}

Values in parentheses are percentages

Table 3. Details of injured patients (excluding those declared dead on arrival)

\begin{tabular}{|c|c|c|c|c|c|c|c|c|c|c|c|c|c|}
\hline \multirow[t]{3}{*}{ Period } & \multicolumn{3}{|c|}{ Mode of transport to hospital } & \multirow{2}{*}{\multicolumn{5}{|c|}{$\begin{array}{l}\text { Time between injury } \\
\text { and arrival at hospital } \\
\text { (h) }\end{array}$}} & \multicolumn{2}{|c|}{ Clothing } & \multicolumn{3}{|c|}{ Experience } \\
\hline & \multirow[t]{2}{*}{ Self } & \multirow[t]{2}{*}{ Ambulance } & \multirow[t]{2}{*}{ Helicopter } & & & & & & \multirow[t]{2}{*}{ Unsuitable } & \multirow[t]{2}{*}{ Suitable } & \multirow[t]{2}{*}{ Little } & \multirow[t]{2}{*}{ Moderate } & \multirow[t]{2}{*}{ Experienced } \\
\hline & & & & 1 & $1-2$ & $2-3$ & $3-5$ & 5 & & & & & \\
\hline \multicolumn{14}{|l|}{ October 1986- } \\
\hline $\begin{array}{l}\text { September } 1987 \\
\text { October 1987- }\end{array}$ & 5 & 6 & 16 & 1 & 6 & 6 & 10 & 4 & 6 & 21 & 9 & 4 & 14 \\
\hline $\begin{array}{l}\text { September } 1988 \\
\text { October 1988- }\end{array}$ & 7 & 6 & 17 & 2 & 1 & 6 & 15 & 6 & 4 & 26 & 5 & 13 & 12 \\
\hline September 1989 & 7 & 12 & 10 & 2 & 3 & 8 & 12 & 4 & 8 & 21 & 9 & 9 & 11 \\
\hline
\end{tabular}

Table 4. Significant injuries sustained

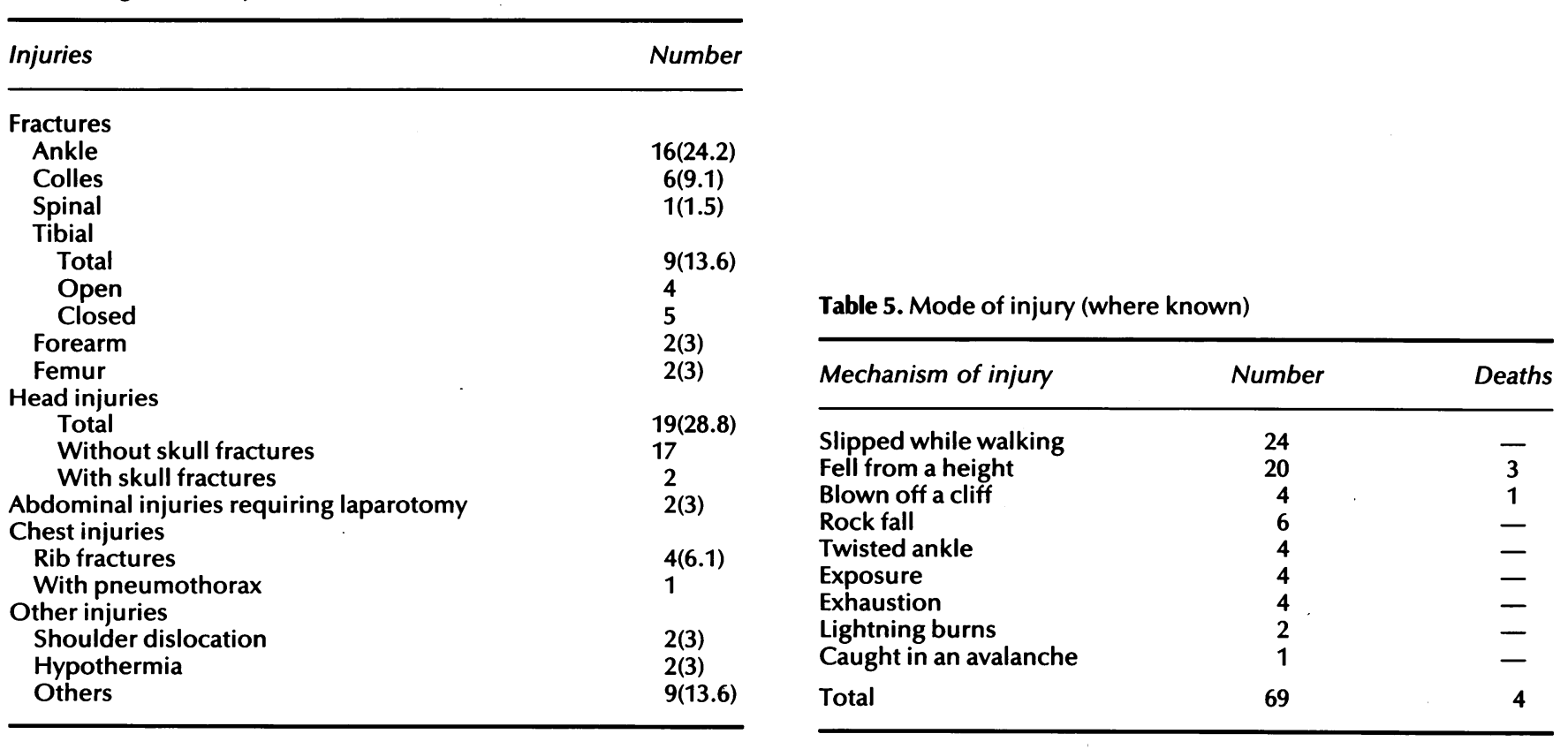

Values in parentheses are percentages 